\title{
Phosphodiesterase 10A IgG
}

\section{A novel biomarker of paraneoplastic neurologic autoimmunity}

Anastasia Zekeridou, MD, Thomas Kryzer, AS, Yong Guo, MD, Anhar Hassan, MD, Vanda Lennon, MD, PhD, Claudia F. Lucchinetti, MD, Sean Pittock, MD, and Andrew McKeon, MD

Neurology ${ }^{\circledR}$ 2019;93:e815-e822. doi:10.1212/WNL.0000000000007971

\section{Abstract}

\section{Objective}

To describe a novel antibody biomarker of neurologic paraneoplastic autoimmunity specific for phosphodiesterase 10A (PDE10A), a striatum-enriched phosphodiesterase, and to characterize the clinical phenotype of patients with PDE10A immunoglobulin G (IgG).

\section{Methods}

We describe 7 patients with autoantibodies specific for PDE10A identified in the Mayo Clinic Neuroimmunology Laboratory. Patient specimens (sera, 7; CSF, 4) produced identical basal ganglia-predominant synaptic staining of murine brain tissue by indirect immunofluorescence. The autoantigen was identified by immunoprecipitation and mass spectrometry as PDE10A, and confirmed by antigen-specific recombinant Western blot and cell-based assays, and immune absorption experiments.

\section{Results}

The median patient age was 70 years (range 66-76); 4 were men. Four patients with clinical information available had movement disorders (hyperkinetic in 3 [chorea, ballismus, dystonia] and parkinsonism in 1). All patients but one had cancer (lung [adenocarcinoma 1, squamous cell carcinoma 1, poorly differentiated mesenchymal carcinoma 1], renal adenocarcinoma 2, and pancreatic adenocarcinoma 1). Two of the 7 patients developed hyperkinetic movement disorders during treatment with immune checkpoint inhibitors (nivolumab and pembrolizumab), though none of 26 cancer control patients treated with immune checkpoint inhibitors harbored PDE10A IgG in their serum. MRIs from those 2 patients with hyperkinetic movement disorders demonstrated fluid-attenuated inversion recovery/T2 basal ganglia hyperintensities, and their CSF harbored unique oligoclonal bands. One of those 2 patients had substantial improvement after corticosteroids. One patient's renal adenocarcinoma expressed PDE10A by immunohistochemistry.

\section{Conclusions}

PDE10A IgG defines a novel rare neurologic autoimmune syndrome and expands the spectrum of diagnosable paraneoplastic CNS disorders. The intracellular location of PDE10A suggests a T-cell-mediated pathology targeting cells displaying MHC1-bound PDE10A peptides.

\author{
Correspondence \\ Dr. Zekeridou \\ zekeridou.anastasia@ \\ mayo.edu
}

\section{RELATED ARTICLE}

\section{Editorial}

PDE10A antibodies in autoimmune encephalitis: A possible marker of cancer immunotherapy?

Page 327

\section{MORE ONLINE}

\section{- Video}

\section{ค Podcast}

Dr. Stacey Clardy talks with Dr. Anastasia

Zekeridou about her paper on phosphodiesterase 10A IgG, a novel biomarker of paraneoplastic neurologic autoimmunity. NPub.org/tmo35v 


\section{Glossary}

CBA = cell-based assay; FLAIR = fluid-attenuated inversion recovery; ICI = immune checkpoint inhibitors; IFA = indirect immunofluorescence assay; IgG = immunoglobulin G; PBS = phosphate-buffered saline; PCA1 = Purkinje-cell cytoplasmic antibody 1; PDE10A = phosphodiesterase 10A; WB = Western blot.

Manifestations of neurologic paraneoplastic autoimmunity can involve any level of the neuraxis. ${ }^{1,2}$ Commonly recognized cancers are small cell lung cancer and thymoma. ${ }^{3,4}$ Immune checkpoint inhibitors (ICI) used for cancer are monoclonal antibodies that neutralize negative regulatory steps in T-cell immune responses, and thus augment antitumor immunity. As a consequence, there is an increase in autoimmune complications, including potentially novel ones. ${ }^{5-7}$

Autoimmune movement disorders have been described in a paraneoplastic context. ${ }^{8-10}$ For example, CRMP5 autoimmunity is accompanied by chorea and T2 basal ganglia MRI hyperintensities. ${ }^{11}$

We describe a novel autoantibody biomarker specific for phosphodiesterase 10A (PDE10A), detected in 7 patients, the majority of whom presented with a movement disorder.

\section{Methods}

\section{Patients}

The Mayo Clinic Neuroimmunology Laboratory database ( $>400,000$ samples tested by indirect immunofluorescence assay using murine tissue from 2011 to 2017) was interrogated for samples with predominant basal ganglia staining. Twenty-one specimens with available quantities were identified and retested by indirect immunofluorescence assay (IFA) using murine tissue. We identified 6 serum and 2 CSF specimens from 5 patients that yielded a similar distinctive immunoglobulin $\mathrm{G}$ ( $\mathrm{IgG}$ ) staining pattern when applied to murine brain. Two more patients (1 serum and 2 CSF specimens) were identified prospectively (total 7 sera and 4 CSFs). Clinical information was abstracted from electronic files ( 1 patient) or provided by referring physicians ( 6 patients). Control sera included 33 healthy participants, 10 patients with Huntington disease, 4 patients with autoimmune CRMP5-related chorea, and 53 patients with carcinomas with or without neurologic autoimmunity not treated with ICI (7 squamous cell, 15 lung adenocarcinomas, 30 renal cell, and 1 renal and squamous cell) and 26 with ICI treatment (single agents or combinations) for different cancers (14 melanoma, 5 non-small cell lung cancer, 3 urothelial carcinomas, 2 neuroendocrine tumors, and 1 each of hepatocellular carcinoma and glioblastoma), with or without associated neurologic autoimmunity.

\section{Standard protocol approvals, registrations, and patient consents}

The Mayo Clinic Institutional Review Board approved this study and patient consent was given for the supplementary video.

\section{Laboratory methods}

Laboratory methods are as previously reported. ${ }^{12}$

\section{Tissue IFA and immunohistochemistry}

Patients' specimens were tested on murine tissue cryosections at screening dilutions of 1:240 (serum; preabsorbed with liver powder) or 1:2 (CSF). The antibody specific for human PDE10A used was a rabbit polyclonal from Invitrogen (Carlsbad, CA) (catalog \# PA5-31293). Secondary antibodies (from SouthernBiotech [Birmingham, $\mathrm{AL}]$ : FITC-labeled goat anti-human IgG and anti-rabbit IgG and TRITC-labeled goat anti-human IgG) were used at 1:200 dilution.

Briefly, sections were fixed with $4 \%$ paraformaldehyde for 1 minute, washed (phosphate-buffered saline $[\mathrm{PBS}]$ ), permeabilized with $0.5 \%$ CHAPS (C32H58N2O7S) for 1 minute, and washed (PBS). Normal goat serum (10\% diluted in PBS) was applied for 1 hour and sections were then incubated with patient serum or CSF for 40 minutes, washed, incubated with secondary antibodies for 30 minutes, and washed.

Formalin-fixed paraffin-embedded sections $(5 \mu \mathrm{m})$ of renal cell carcinoma from patient 4 and normal human kidney were stained immunohistochemically using the specific PDE10A antibody (1:500 dilutions) with overnight incubation at $4^{\circ} \mathrm{C}$.

\section{Protein characterization}

\section{Antigen preparation}

Porcine basal ganglia were identified macroscopically, dissected, frozen, and stored at $-80^{\circ} \mathrm{C}$. Immunoreactivity of patients' sera was confirmed in cryosections by IFA. Cytoplasmic and membrane extraction fractions were prepared. In brief, homogenized tissue $(250 \mathrm{mM}$ sucrose, $50 \mathrm{mM}$ Tris$\mathrm{HCl}$ [pH 7.4], $5 \mathrm{mM} \mathrm{MgCl}, 1 \mathrm{mM} \mathrm{DTT}$, and protease inhibitor tablets [cOmplete, Mini; Sigma-Aldrich, St. Louis, $\mathrm{MO}]$ ) was centrifuged at $800 \mathrm{~g}$ twice to remove nuclei. The clarified supernatant (after centrifugation at $100,000 \mathrm{~g}$ ) was stored at $-80^{\circ} \mathrm{C}$ (cytoplasmic fraction). The pellet was extracted for 1 hour (20 mM Tris- $\mathrm{HCl}[\mathrm{pH} 7.8], 0.4 \mathrm{M} \mathrm{NaCl}$, $15 \%$ glycerol, $1.5 \%$ Triton-X, $1 \mathrm{mM} \mathrm{DTT}$, and protease inhibitors), centrifuged at $10,000 \mathrm{~g}$, and the supernatant (membrane extraction fraction) was stored at $-80^{\circ} \mathrm{C}$. Immunoreactivity with patients' sera was found in both fractions by Western blot (WB), but was more intense in the membrane fraction that was used for further antigen characterization experiments. 

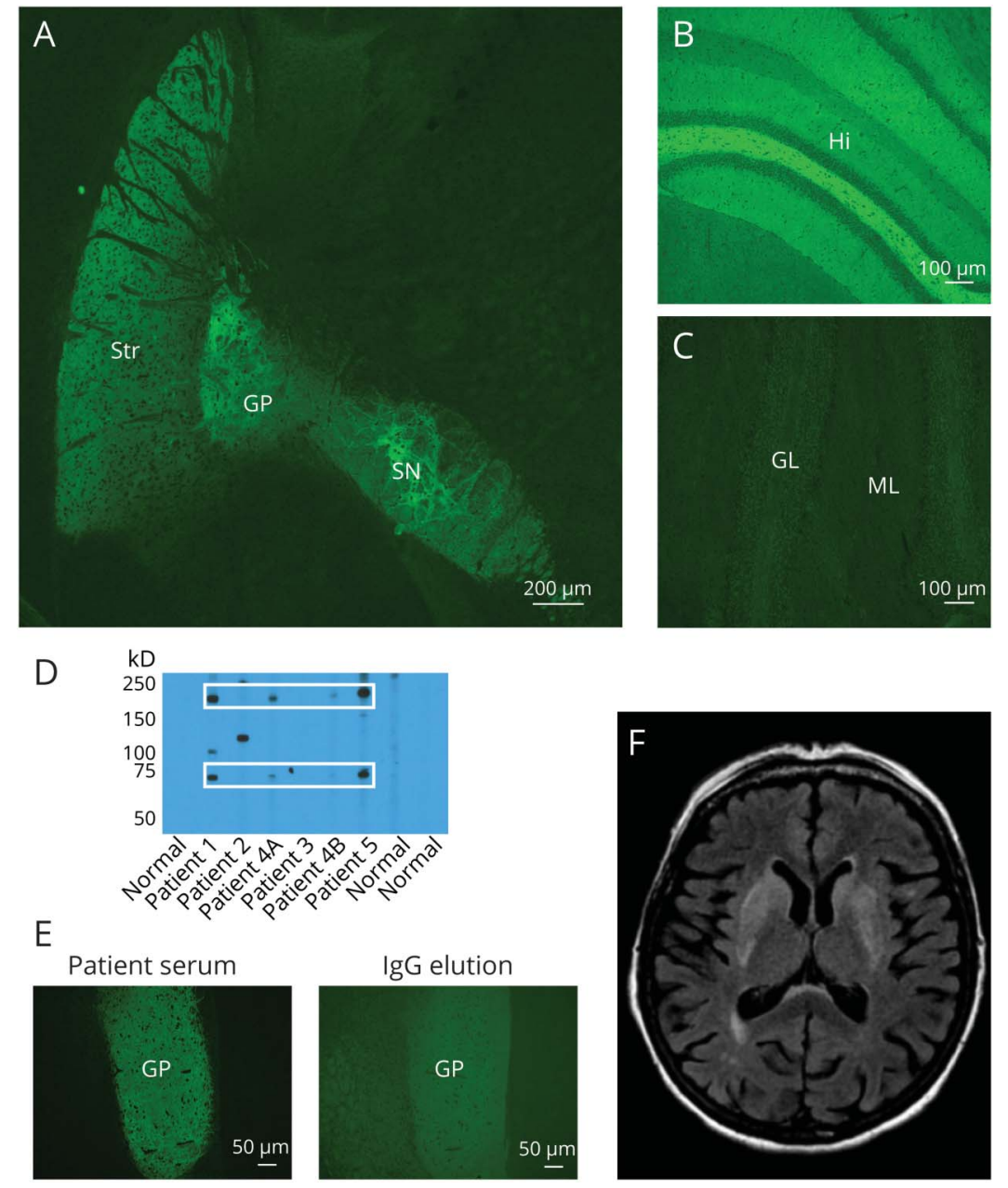

Indirect immunofluorescence assay performed on murine tissue with patient serum demonstrates synaptic staining of the basal ganglia (A), more prominent than the hippocampus (B) and to a lesser extent the granular layer of the cerebellum (C). (D) Western blot probing of lysed membrane fraction of pig basal ganglia with serum immunoglobulin $\mathrm{G}$ (IgG) of 3 patients identified an immunoreactive band $\sim 75 \mathrm{kDa}$ and another $>200 \mathrm{kDa}$ that were not seen with normal control serum IgG. Elution of patient 1's IgG from the corresponding $75 \mathrm{kDa}$ excised nitrocellulose band reproduced the original tissue staining pattern when applied to mouse brain as the patient's serum (E), while an IgG elution from a control band ( 150 kDa) did not (not shown). (F) T2 fluidattenuated inversion recovery MRI of patient 4 with bilateral basal ganglial hyperintensities. $\mathrm{GL}=$ granular layer; $\mathrm{GP}=$ globus pallidus; $\mathrm{Hi}=$ hippocampus; $\mathrm{ML}=$ molecular layer; SN = substantia nigra; Str = striatum.

\section{Antibody purification and protein characterization}

Patients' IgG was purified using protein G bound to magnetic beads (Dynabeads; Invitrogen) and incubated with pig basal ganglia membrane extraction. IgG and bound protein were eluted and dissociated by boiling in sodium dodecyl sulfate sample buffer and separated by gel electrophoresis. Silver staining and WB were used to identify the immunoreactive bands that were subsequently sequenced by mass spectrometry. To confirm that those immunoreactive bands contained the antigen yielding the tissue IFA pattern, we eluted the IgGs from excised nitrocellulose bands of corresponding molecular weight and tested eluates by tissue IFA.

\section{Specific protein-target confirmation assays}

\section{Western blot}

Commercially available recombinant human PDE10A protein (Abcam, ab198428; $\geq 48 \%$ purity, expected MW $116 \mathrm{kDa}$ ) was used for WB to confirm the patients' antibody immunoreactivity.

\section{Absorption of patient serum IgGs with recombinant PDE10A}

Three patients' sera and a control serum (positive for Purkinje-cell cytoplasmic antibody 1 [PCA1], also known as anti-Yo) were incubated overnight with either $2 \mu \mathrm{g}$ of recombinant PDE10A or PBS and tested by IFA.

\section{Cell-based immunofluorescence assays}

HEK293 cells were transiently transfected with plasmids encoding either PDE10A1 or PDE10A2 isoforms (GenScript, reference sequence: NM_001130690.2 and NM_006661.3), fixed and tested by IFA. Patient sera and CSFs (1:200 and 1:5 dilutions, respectively) and PDE10A rabbit polyclonal commercial antibody (1:300 dilution) were applied and secondary antibodies used, as above. All patient and control specimens yielded the same results, regardless of the PDE10A isoform used.

\section{Data availability}

All methods are available above and data are published in this article. 
A

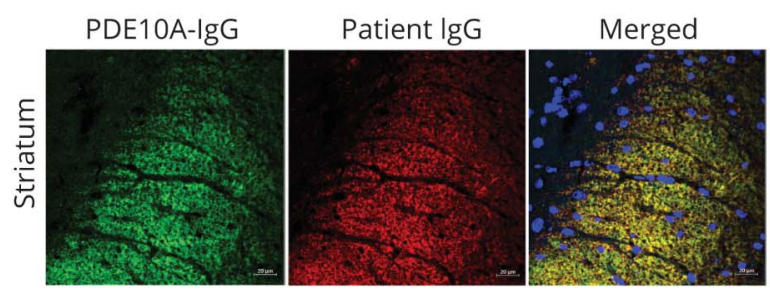

C

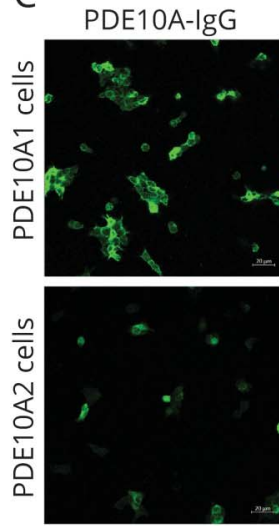

PDE10A-IgG

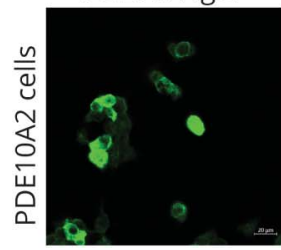

Patient lgG
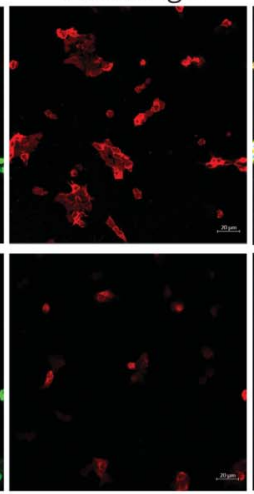

Control-IgG

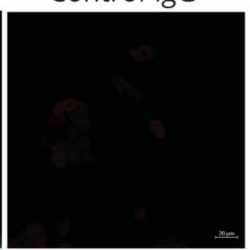

Merged

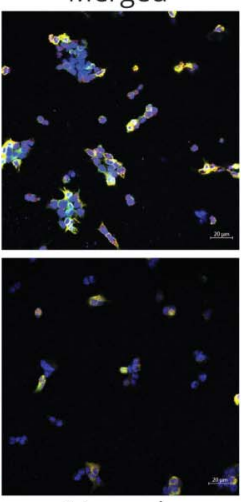

Merged

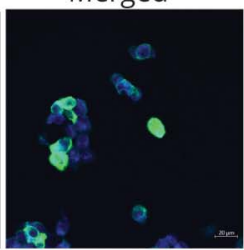

B



D

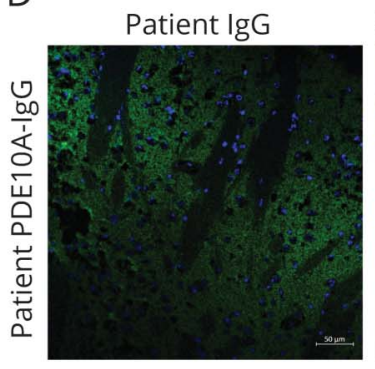

Post-PDE10A absorption

Patient IgG

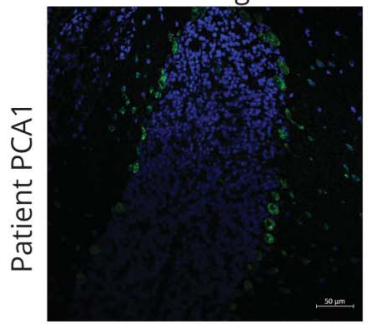

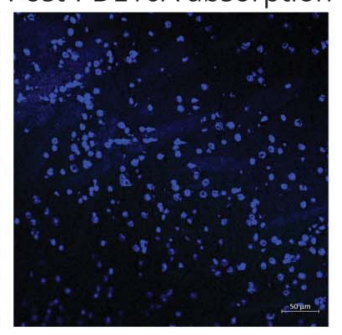

Post-PDE10A absorption

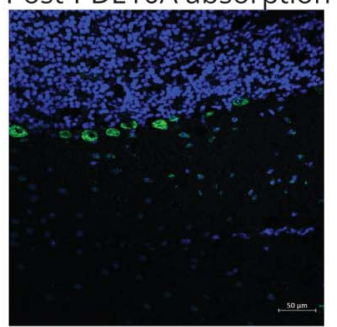

(A) Rabbit phosphodiesterase 10A (PDE10A) immunoglobulin G (IgG) (green) colocalizes with patient serum IgG (red) by confocal indirect immunofluorescence imaging on murine basal ganglia (merged images; yellow). Nuclei are blue (DAPI stained). (B) Recombinant PDE10A Western blot (WB) of 5 patients (6 sera; patient 4 had sera from 2 timepoints) and normal controls. The 2 patients whose serum lacked 75 kDa reactivity in WB testing with pig basal ganglia extracts (figure 1D) were positive by recombinant WB but yielded a less intense signal than the other patients' sera. (C) Cell-based indirect immunofluorescence, commercial PDE10A IgG (green), patient's serum (red), and merged images (yellow); nuclear staining in blue (DAPI). (D) Immune absorption of PDE10A-IgG-positive patient's serum with $2 \mu \mathrm{g}$ of recombinant PDE10A protein eliminates the basal ganglia staining by indirect immunofluorescence while the control Purkinje-cell cytoplasmic antibody 1 (PCA1)-IgG-positive serum's staining in the perikarya of cerebellar Purkinje neurons is unchanged when absorbed with the same amount of recombinant PDE10A protein.

\section{Results}

\section{Antigen characterization}

All patients' specimens yielded the same synaptic immunofluorescence pattern of IgG binding, with prominent staining of the basal ganglia and related nuclei, to a lesser extent the hippocampus, and faint staining of the cerebellar granular layer (figure $1, \mathrm{~A}-\mathrm{C}$ ). None of the $>400,000$ clinical samples tested in the same period had similar staining.

WB of patients' sera using pig basal ganglia extracts revealed a common band (approximate MW $75 \mathrm{kDa}$ ) in 3 patients (figure 1D). IgG eluted from the nitrocellulose-corresponding band demonstrated the same staining pattern by tissue IFA as the patients' serum (figure $1 \mathrm{E}$ ), but not IgG eluted from a control band $(\sim 150 \mathrm{kDa})$. Eluates derived from immunoprecipitation experiments using purified IgG (patients 1 and 4 and one healthy control) were treated by in-gel digestion and proteins were identified by mass spectrometry. The majority of peptides identified from the excised gel bands of the 2 patients but not of the control corresponded to fragments of PDE10A (MW in pig: $79 \mathrm{kDa}$ ), including from a second common band above $200 \mathrm{kDa}$.

\section{Confirmation of PDE10A as autoantigen}

PDE10A was confirmed as the pertinent antigen (figure 2, A-D). First, there was colocalization on murine brain IFA of all patients' specimens with the PDE10A-specific antibody by confocal microscopy. Second, IgG in patients' sera bound to recombinant PDE10A in WB testing, while normal controls were negative. Third, preabsorption of serum from patients 3 , 4 , and 5 (but not from a patient harboring PCA1) with recombinant PDE10A protein eliminated the specific IFA staining. Finally, all specimens were positive by indirect immunofluorescence on PDE10A-transfected HEK cell-based assays (CBA), both with PDE10A1 and PDE10A2 isoforms. 
All controls were negative except for 1 patient with renal adenocarcinoma and aquaporin-4-IgG-seropositive neuromyelitis optica that had faint reactivity on PDE10A-transfected cells by CBA but was negative for the characteristic tissue IFA staining and recombinant PDE10A WB.

\section{Clinical characteristics}

The patients' clinical characteristics are summarized in the table. The patients' median age was 70 years (range 66-76 years); 4 were male (57\%). Neurologic information was available in 6 cases, although limited in 4 . Three patients had hyperkinetic movements (chorea, generalized dystonia and choreiform movements, right hemiballismus). One additional patient had parkinsonism. Four patients had encephalopathy, 2 of whom had meningeal carcinomatosis.

All patients had confirmed carcinomas, except for patient 2, in whom a lung nodule was radiologically detected. Carcinomas encountered were pulmonary non-small cell type (1 adenocarcinoma, 1 squamous cell, 1 poorly differentiated mesenchymal), 2 metastatic renal cell, and 1 pancreatic.

Two patients developed neurologic symptoms a median of 4.5 months (range 4-5) after initiation of ICI therapy targeting PD1 for adenocarcinoma of kidney and lung. Both patients had hyperkinetic movement disorders and basal ganglial fluidattenuated inversion recovery (FLAIR)/T2 hyperintensities (nonenhancing) on MRI that recapitulated the appearance of patient IgG staining observed on mouse brain by IFA (figure $1 F$ ). This MRI finding was not reported in other patients with imaging data, but the imaging were not available for review by the authors. Both patients had CSF-restricted oligoclonal bands.

Only these 2 patients received immunotherapy. Patient 4 improved after a course of IV methylprednisolone and pembrolizumab cessation (video), but the benefit eventually

Table Patients with confirmed phosphodiesterase 10A (PDE10A) autoimmunity

\begin{tabular}{|c|c|c|c|c|c|c|c|}
\hline & $\begin{array}{l}\text { Main neurologic } \\
\text { symptoms }\end{array}$ & Cancer & $\begin{array}{l}\text { Cancer } \\
\text { treatment }\end{array}$ & $\begin{array}{l}\text { PDE10A } \\
\text { IgG }\end{array}$ & CSF & MRI & Treatment/outcome \\
\hline $\begin{array}{l}1 / \\
\mathrm{M} / \\
71^{\mathrm{a}}\end{array}$ & Not available & $\begin{array}{l}\text { Right lung; poorly } \\
\text { differentiated } \\
\text { mesenchymal } \\
\text { neoplasm }\end{array}$ & NA & $\begin{array}{l}\text { Serum } \\
\text { titer: }>1 \text { : } \\
30,720 \\
\text { (CSF NA) }\end{array}$ & NA & $\begin{array}{l}\text { Age-appropriate } \\
\text { changes } \\
\text { reported }\end{array}$ & Death (no data available) \\
\hline $\begin{array}{l}21 \\
\mathrm{M} / \\
75^{\mathrm{a}}\end{array}$ & $\begin{array}{l}\text { Chorea and } \\
\text { encephalopathy }\end{array}$ & $\begin{array}{l}\text { Lung nodule; no } \\
\text { follow-up }\end{array}$ & NA & $\begin{array}{l}\text { Serum } \\
\text { titer: } 1 \text { : } \\
\text { 15,360 } \\
\text { (CSF NA) }\end{array}$ & NA & NA & NA \\
\hline $\begin{array}{l}3 / \\
F / \\
69^{\mathrm{a}}\end{array}$ & $\begin{array}{l}\text { Encephalopathy } \\
\text { (confusion) and } \\
\text { dysarthria }\end{array}$ & $\begin{array}{l}\text { Squamous cell lung } \\
\text { cancer; remote } \\
\text { history of large } \\
\text { meningioma } \\
\text { radiated }\end{array}$ & NA & $\begin{array}{l}\text { Serum } \\
\text { titer: } \\
1: 30,720 \\
\text { (CSF NA) }\end{array}$ & NA & NA & Death (no data available) \\
\hline $\begin{array}{l}4 / \\
F / \\
76\end{array}$ & $\begin{array}{l}\text { Generalized } \\
\text { hyperkinetic } \\
\text { movement disorder } \\
\text { (chorea, dyskinesia), } \\
\text { dysarthria, and } \\
\text { dysphagia }\end{array}$ & $\begin{array}{l}\text { Metastatic renal cell } \\
\text { carcinoma (vena } \\
\text { cava, brain, liver) }\end{array}$ & $\begin{array}{l}5 \text { months after } \\
\text { onset of } \\
\text { pembrolizumab } \\
\text { treatment }\end{array}$ & $\begin{array}{l}\text { Serum } \\
\text { titer: }>1 \text { : } \\
30,720 \\
\text { and CSF: } \\
\text { titer NA }\end{array}$ & $\begin{array}{l}\text { WBCs } \\
\leq 5, \text { Pro, } \\
44 \mathrm{mg} / \\
\mathrm{dL}, 8 \\
\text { OCBs }\end{array}$ & $\begin{array}{l}\text { FLAIR/T2 BG } \\
\text { hyperintensities }\end{array}$ & $\begin{array}{l}\text { Pembrolizumab cessation; IVMP } \\
\rightarrow \text { improvement of the movement } \\
\text { disorder; not sustained, no } \\
\text { response to PLEX or oral steroids; } \\
\text { cancer remission for } 3 \text { years }\end{array}$ \\
\hline $\begin{array}{l}5 / \\
F / \\
66\end{array}$ & $\begin{array}{l}\text { Right hemiballismus } \\
\text { and dysarthria }\end{array}$ & $\begin{array}{l}\text { Lung } \\
\text { adenocarcinoma }\end{array}$ & $\begin{array}{l}4 \text { months after } \\
\text { onset of } \\
\text { nivolumab } \\
\text { treatment }\end{array}$ & $\begin{array}{l}\text { Serum } \\
\text { titer } \\
>30,720 \\
\text { and CSF } \\
\text { titer: } 1: 4\end{array}$ & $\begin{array}{l}\text { WBCs } \\
\leq 5, \text { Pro, } \\
56 \mathrm{mg} / \\
\mathrm{dL}, 14 \\
\text { OCBs }\end{array}$ & $\begin{array}{l}\text { FLAIR/T2 BG } \\
\text { hyperintensities }\end{array}$ & $\begin{array}{l}\text { Nivolumab cessation; IVMP, PLEX, } \\
\text { IVIg, RTX } \rightarrow \text { no improvement; } \\
\text { death soon after from neurologic } \\
\text { deterioration }\end{array}$ \\
\hline $\begin{array}{l}6 / \\
\mathrm{M} / \\
70^{\mathrm{a}}\end{array}$ & $\begin{array}{l}\text { Parkinsonism, } \\
\text { encephalopathy } \\
\text { (confusion) }\end{array}$ & $\begin{array}{l}\text { Metastatic renal cell } \\
\text { carcinoma with } \\
\text { probable } \\
\text { leptomeningeal } \\
\text { carcinomatosis }\end{array}$ & NA & $\begin{array}{l}\text { Serum } \\
\text { and CSF; } \\
\text { titers NA }\end{array}$ & NA & $\begin{array}{l}\text { Leptomeningeal } \\
\text { enhancement }\end{array}$ & Death (no data available) \\
\hline $\begin{array}{l}71 \\
\mathrm{M} / \\
69^{\mathrm{a}}\end{array}$ & $\begin{array}{l}\text { Subacute ataxia, } \\
\text { encephalopathy } \\
\text { (hearing loss, } \\
\text { headache, and } \\
\text { confusion) }\end{array}$ & $\begin{array}{l}\text { Metastatic } \\
\text { pancreatic } \\
\text { adenocarcinoma } \\
\text { (liver, lung, and } \\
\text { probable meningeal } \\
\text { carcinomatosis) }\end{array}$ & NA & $\begin{array}{l}\text { CSF titer: } \\
1: 64 \\
\text { (serum } \\
\text { NA) }\end{array}$ & NA & $\begin{array}{l}\text { Leptomeningeal } \\
\text { enhancement }\end{array}$ & $\begin{array}{l}\text { Death from cancer complications } \\
\text { (no data available) }\end{array}$ \\
\hline
\end{tabular}

Abbreviations: BG = basal ganglia; FLAIR = fluid-attenuated inversion recovery; IgG = immunoglobulin G; IVIg = IV immunoglobulin; IVMP = IV methylprednisolone; $N A=$ not available; $O C B$ = oligoclonal band; PLEX = plasma exchange; pro = protein; $\mathrm{RTX}=$ rituximab; $\mathrm{WBC}=$ white blood cell.

Normal values for CSF: pro, $\leq 35 \mathrm{mg} / \mathrm{dL} ;$ OCBs, $<4$; WBC, $\leq 5 / \mu \mathrm{L}$.

a Patients with limited clinical information. 
subsided; sustained improvement occurred after tetrabenazine and craniocervical botulinum toxin injections. The patient was alive 3 years after diagnosis of a plurimetastatic renal cell adenocarcinoma. Patient 5, who developed hemiballismus while on ICI for lung adenocarcinoma, had no response to any immunotherapy. She died of neurologic complications soon after onset of her symptoms (table).

Of the remaining patients, 4 died shortly after neurologic symptom onset (patients 1, 3, 6, and 7) or was lost to follow-up (patient 2).

\section{Immunohistochemical testing of renal tissues for PDE10A}

PDE10A-specific IgG produced diffuse staining of patient 4's renal adenocarcinoma (figure 3, C-F), while normal kidney tissue showed PDE10A expression restricted to tubular epithelium (figure 3, A and B).

\section{Discussion}

We report PDE10A-specific IgG as a biomarker of paraneoplastic neurologic autoimmunity with most prominent clinical phenotype of movement disorders with or without coexisting encephalopathy. The clinical phenotype might be broader than what we describe because the clinical data available were limited. A carcinoma was diagnosed in all but one patient. ICI targeting PD-1 were implicated as the trigger of neurologic symptoms in 2 patients, one of whom responded favorably to corticosteroid therapy initially. Paralleling the clinical phenotype, PDE10A IgG staining of mouse brain was most prominent in the basal ganglia and hippocampus. In addition, MRI of 2 patients with hyperkinetic movement disorders revealed basal ganglial FLAIR/T2 hyperintensities.

A similar phenotype (generalized hyperkinetic movement disorder and bilateral striatal lesions on MRI) in children with PDE10A mutations parallels this autoimmune phenotype. $^{13,14}$ PET studies showed that PDE10A expression is altered early in another choreiform disorder, Huntington disease, and in presymptomatic carriers. ${ }^{15,16}$ None of the patients with Huntington disease we tested had PDE10A IgGs.

The enzyme PDE10A, a dual-substrate cyclic nucleotide phosphodiesterase that hydrolyzes adenosine and guanosine $3^{\prime}, 5^{\prime}$-cyclic monophosphates, is enriched in striatal medium

Figure 3 Immunohistochemistry of renal cell carcinoma (patient 4)
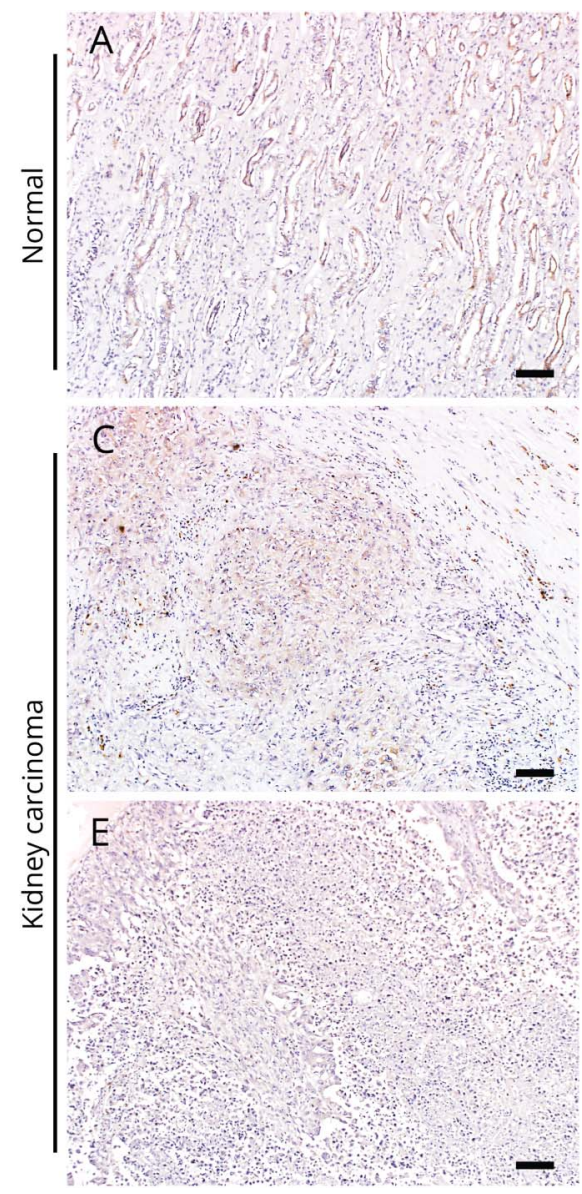

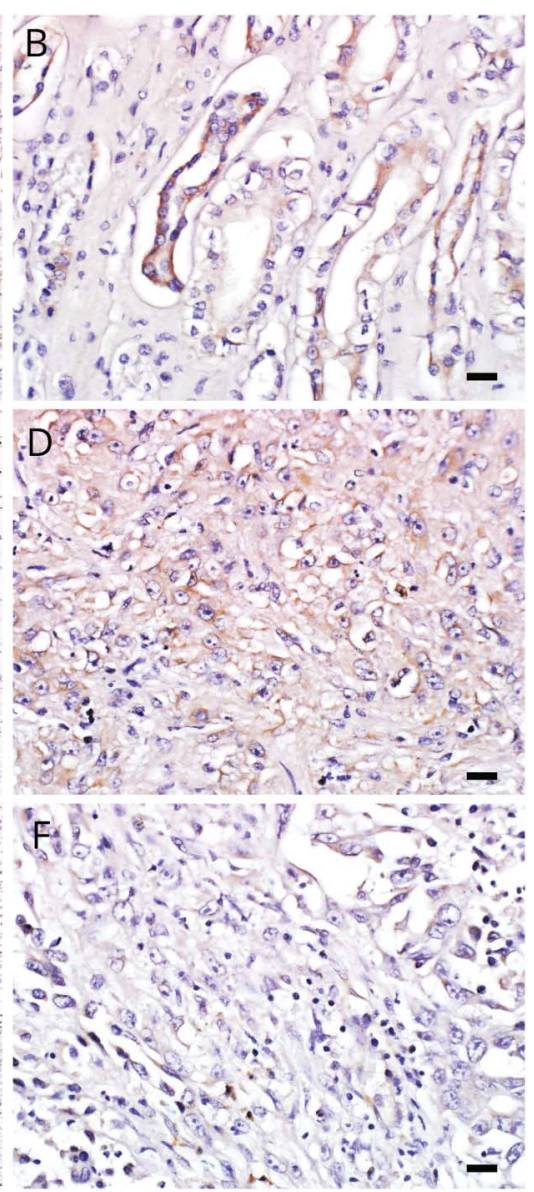

(A, B) Phosphodiesterase 10A (PDE10A) immunohistochemistry in normal control human kidney tissue. The high power image (B) indicates the collecting tubular epithelium with marked expression of PDE10A. The kidney carcinoma tissue of patient 4 shows foci of variable PDE10A immunoreactivity: moderate expression $(C, D)$ or scant PDE10A expression $(E, F)$ in different parts of the tumor. Scale bars in $A, C$, and $E=100 \mu \mathrm{m}$. Scale bars in $B, D$, and $F=20 \mu \mathrm{m}$. 
spiny neurons. ${ }^{17,18}$ It is an intracellular protein, mostly membrane-bound (PDE10A1 isoform), but also free in the cytoplasm (PDE10A2), consistent with our patients' IgGs binding to both membrane and cytoplasmic fractions of pig basal ganglia extracts. ${ }^{19}$ Our patient specimens were immunoreactive with both PDE10A isoforms.

The intracellular location of PDE10A suggests that patients' IgG, unlike NMDA receptor IgG, lacks potential for neuralspecific pathogenicity, but rather is a surrogate marker of cytotoxic T cells specific for PDE10A-derived peptides. ${ }^{2,20,21}$ The foci of PDE10A immunoreactivity in the renal cell adenocarcinoma of patient 4 supports a peripheral carcinoma being the initial immunogenic trigger for an autoimmune response. $^{22,23}$ A single control patient with renal cell adenocarcinoma had low PDE10A-IgG seropositivity by CBA alone, suggesting a possible onconeural antigen-specific antitumor immune response without the corresponding neurologic phenotype. ${ }^{3,24}$ Neither this patient's renal cell carcinoma nor control renal cell carcinomas were tested for PDE10A expression in this study, but mRNA data suggest that PDE10A can be expressed in kidney tumors (proteinatlas.org). The immunologic trigger for bypassing self-tolerance and deknown but expression of neoantigens by the tumors has been implicated. .2,23,25 $^{2}$

It was remarkable that 2 of our 7 patients harboring PDE10A IgG received ICI treatment before the onset of an autoimmune hyperkinetic disorder. Sera of control patients with different types of cancer with and without neurologic disease that were treated with ICI were all negative for PDE10A IgG. Thus, at this early stage, we do not know if patients treated with immune checkpoint inhibitors are at higher risk for this specific autoimmune hyperkinetic movement disorder or not.

Cancers that heretofore rarely associated with paraneoplastic neurologic autoimmunity are encountered increasingly in contemporary practice after introduction of ICI; for example, renal cell adenocarcinomas, well-known for triggering metabolic endocrine paraneoplastic syndromes rarely associated with neurologic autoimmunity. ${ }^{26}$ Neurologic autoimmunity in these cases is probably facilitated by the potentiation of the antitumor immune response by the ICIs, as seen in other wellestablished autoimmune diseases that develop after ICI treatments; the autoimmune complications do not appear to be drug-specific but likely related to the immunologic background of the patient and neoplasm type. ${ }^{27}$

PDE10A autoimmunity, although rare, expands the spectrum of diagnosable autoimmune movement disorders, may be severe, and should be suspected in patients with movement disorders, especially if treated with cancer immunotherapy. Early diagnosis and treatment with appropriate immunotherapy may prevent further neurologic deterioration, though our initial data seem to portend a poor prognosis. velopment of antigen-specific autoimmunity remains un-

\section{Acknowledgment}

The authors thank James Fryer, Jade Zbacnik, and James Checkel for technical assistance and Avi Gadoth, MD, and Sebastian Alfonso Lopez-Chiriboga, MD, for gathering part of the clinical information.

\section{Study funding}

No targeted funding reported.

\section{Disclosure}

A. Zekeridou has a pending patent application pertaining to PDE10A-IgG autoimmunity. T. Kryzer receives royalties from licensing of aquaporin-4 IgG as diagnostic aid. Y. Guo and A. Hassan report no disclosures relevant to the manuscript. V.A. Lennon receives royalties for technology relating to aquaporin-4 (AQP4) antibodies for diagnosis of neuromyelitis optica (NMO) and its spectrum disorders and is a named inventor on filed patents that relate to functional AQP4/NMO-IgG assays and NMO-IgG as a cancer marker. C.F. Lucchinetti reports no disclosures relevant to the manuscript. S.J. Pittock has a financial interest in technology associated with "Aquaporin-4 autoantibody as a cancer marker," "Aquaporin-4 binding autoantibodies in patients with neuromyelitis optica impair glutamate transport by down-regulating EAAT2," and "MAP1B as a paraneoplastic biomarker." Dr. Pittock receives research support from Alexion, Medimmune, and Grifols. Dr. Pittock has provided consultation to Alexion Pharmaceutical, MedImmune LLC, and Chugai Pharma, but has received no personal fees or compensation for these consulting activities. All compensation for consulting activities is paid directly to Mayo Clinic. A. McKeon has a pending patent application pertaining to PDE10A IgG autoimmunity. Go to Neurology.org/N for full disclosures.

\section{Publication history}

Received by Neurology November 23, 2018. Accepted in final form May 1, 2019.

Appendix Authors

\begin{tabular}{llll}
\hline Name & Location & Role & Contribution \\
\hline $\begin{array}{l}\text { Anastasia } \\
\text { Mekeridou, }\end{array}$ & $\begin{array}{l}\text { Mayo } \\
\text { Clinic, } \\
\text { Rochester, } \\
\text { MN }\end{array}$ & Author & $\begin{array}{l}\text { Design and conceptualization of } \\
\text { the study, major role in } \\
\text { acquisition and analysis and } \\
\text { interpretation of the data, } \\
\text { drafted the manuscript for } \\
\text { intellectual content }\end{array}$ \\
$\begin{array}{l}\text { Thomas } \\
\text { Kryzer, AS }\end{array}$ & $\begin{array}{l}\text { Mayo } \\
\text { Clinic, } \\
\text { Rochester, }\end{array}$ & Author & $\begin{array}{l}\text { Interpretation of the data, } \\
\text { revising the manuscript for } \\
\text { intellectual content }\end{array}$ \\
\hline $\begin{array}{l}\text { Mong Guo, } \\
\text { MD }\end{array}$ & $\begin{array}{l}\text { Mayo } \\
\text { Clinic, } \\
\text { Rochester, } \\
\text { MN }\end{array}$ & Author & $\begin{array}{l}\text { Major role in the acquisition and } \\
\text { analysis and interpretation of } \\
\text { data, revising the manuscript } \\
\text { for intellectual content }\end{array}$ \\
& & &
\end{tabular}


Appendix (continued)

\begin{tabular}{|c|c|c|c|}
\hline Name & Location & Role & Contribution \\
\hline $\begin{array}{l}\text { Anhar } \\
\text { Hassan, MD }\end{array}$ & $\begin{array}{l}\text { Mayo } \\
\text { Clinic, } \\
\text { Rochester, } \\
\text { MN }\end{array}$ & Author & $\begin{array}{l}\text { Major role in the acquisition of } \\
\text { data, revising the manuscript } \\
\text { for intellectual content }\end{array}$ \\
\hline $\begin{array}{l}\text { Vanda } \\
\text { Lennon, MD, } \\
\text { PhD }\end{array}$ & $\begin{array}{l}\text { Mayo } \\
\text { Clinic, } \\
\text { Rochester, } \\
\text { MN }\end{array}$ & Author & $\begin{array}{l}\text { Interpretation of the data, } \\
\text { revising the manuscript for } \\
\text { intellectual content }\end{array}$ \\
\hline $\begin{array}{l}\text { Claudia F. } \\
\text { Lucchinetti, } \\
\text { MD }\end{array}$ & $\begin{array}{l}\text { Mayo } \\
\text { Clinic, } \\
\text { Rochester, } \\
\text { MN }\end{array}$ & Author & $\begin{array}{l}\text { Interpretation of the data, } \\
\text { revising the manuscript for } \\
\text { intellectual content }\end{array}$ \\
\hline $\begin{array}{l}\text { Sean } \\
\text { Pittock, MD }\end{array}$ & $\begin{array}{l}\text { Mayo } \\
\text { Clinic, } \\
\text { Rochester, } \\
\text { MN }\end{array}$ & Author & $\begin{array}{l}\text { Interpretation of the data, } \\
\text { revising the manuscript for } \\
\text { intellectual content }\end{array}$ \\
\hline $\begin{array}{l}\text { Andrew } \\
\text { McKeon, MD }\end{array}$ & $\begin{array}{l}\text { Mayo } \\
\text { Clinic, } \\
\text { Rochester, } \\
\text { MN }\end{array}$ & Author & $\begin{array}{l}\text { Design and conceptualization of } \\
\text { the study, major role in } \\
\text { acquisition and analysis and } \\
\text { interpretation of data, revised } \\
\text { the manuscript for intellectual } \\
\text { content }\end{array}$ \\
\hline
\end{tabular}

\section{References}

1. McKeon A, Pittock SJ. Paraneoplastic encephalomyelopathies: pathology and mechanisms. Acta Neuropathol 2011;122:381-400.

2. Lancaster E, Dalmau J. Neuronal autoantigens: pathogenesis, associated disorders and antibody testing. Nat Rev Neurol 2012;8:380-390.

3. Zekeridou A, McKeon A, Lennon VA. Frequency of synaptic autoantibody accompaniments and neurological manifestations of thymoma. JAMA Neurol 2016;73: 853-859.

4. Gozzard P, Woodhall M, Chapman C, et al. Paraneoplastic neurologic disorders in small cell lung carcinoma: a prospective study. Neurology 2015;85:235-239.

5. Hottinger AF. Neurologic complications of immune checkpoint inhibitors. Curr Opin Neurol 2016;29:806-812.

6. Kao JC, Liao B, Markovic SN, et al. Neurological complications associated with antiprogrammed death 1 (PD-1) antibodies. JAMA Neurol 2017;74:1216-1222.
7. Touat M, Talmasov D, Ricard D, Psimaras D. Neurological toxicities associated with immune-checkpoint inhibitors. Curr Opin Neurol 2017;30:659-668.

8. Honorat JA, McKeon A. Autoimmune movement disorders: a clinical and laboratory approach. Curr Neurol Neurosci Rep 2017;17:4.

9. Damato V, Balint B, Kienzler AK, Irani SR. The clinical features, underlying immunology, and treatment of autoantibody-mediated movement disorders. Mov Disord 2018;33:1376-1389.

10. Balint B, Vincent A, Meinck HM, Irani SR, Bhatia KP. Movement disorders with neuronal antibodies: syndromic approach, genetic parallels and pathophysiology. Brain 2018;141:13-36.

11. Vernino S, Tuite P, Adler $\mathrm{CH}$, et al. Paraneoplastic chorea associated with CRMP-5 neuronal antibody and lung carcinoma. Ann Neurol 2002;51:625-630.

12. Basal E, Zalewski N, Kryzer TJ, et al. Paraneoplastic neuronal intermediate filament autoimmunity. Neurology 2018;91:e1677-e1689.

13. Diggle CP, Sukoff Rizzo SJ, Popiolek M, et al. Biallelic mutations in PDE10A lead to loss of striatal PDE10A and a hyperkinetic movement disorder with onset in infancy. Am J Hum Genet 2016;98:735-743.

14. Miyatake S, Koshimizu E, Shirai I, et al. A familial case of PDE10A-associated childhood-onset chorea with bilateral striatal lesions. Mov Disord 2018;33:177-179.

15. Niccolini F, Haider S, Reis Marques T, et al. Altered PDE10A expression detectable early before symptomatic onset in Huntington's disease. Brain 2015;138:3016-3029.

16. Wilson H, De Micco R, Niccolini F, Politis M. Molecular imaging markers to track Huntington's disease pathology. Front Neurol 2017;8:11.

17. Fujishige K, Kotera J, Michibata H, Yuasa S, Okumura K, Omori K. Cloning and characterization of a novel human phosphodiesterase that hydrolyzes both cAMP and cGMP (PDE10A). J Biol Chem 1999;274:18438-18445.

18. Loughney K, Snyder PB, Uher L, Rosman GJ, Ferguson K, Florio VA. Isolation and characterization of PDE10A, a novel human 3', 5'-cyclic nucleotide phosphodiesterase. Gene 1999;234:109-117.

19. Xie Z, Adamowicz WO, Eldred WD, et al. Cellular and subcellular localization of PDE10A, a striatum-enriched phosphodiesterase. Neuroscience 2006;139:597-607.

20. Dalmau J, Geis C, Graus F. Autoantibodies to synaptic receptors and neuronal cell surface proteins in autoimmune diseases of the central nervous system. Physiol Rev 2017;97:839-887

21. Crisp SJ, Kullmann DM, Vincent A. Autoimmune synaptopathies. Nat Rev Neurosci 2016;17:103-117.

22. Zekeridou A, Griesmann GE, Lennon VA. Mutated cancer autoantigen implicated cause of paraneoplastic myasthenia gravis. Muscle Nerve 2018;58:600-604.

23. Small M, Treilleux I, Couillault C, et al. Genetic alterations and tumor immune attack in Yo paraneoplastic cerebellar degeneration. Acta Neuropathol 2018;135:569-579.

24. Gozzard P, Chapman C, Vincent A, Lang B, Maddison P. Novel humoral prognostic markers in small-cell lung carcinoma: a prospective study. PLoS ONE 2015;10:e143558.

25. Joseph CG, Darrah E, Shah AA, et al. Association of the autoimmune disease scleroderma with an immunologic response to cancer. Science 2014;343:152-157.

26. Palapattu GS, Kristo B, Rajfer J. Paraneoplastic syndromes in urologic malignancy: the many faces of renal cell carcinoma. Rev Urol 2002;4:163-170.

27. Mammen AL, Rajan A, Pak K, et al. Pre-existing antiacetylcholine receptor autoantibodies and B cell lymphopaenia are associated with the development of myositis in patients with thymoma treated with avelumab, an immune checkpoint inhibitor targeting programmed death-ligand 1. Ann Rheum Dis 2019;78:150-152. 


\section{Neurology}

\section{Phosphodiesterase 10A IgG: A novel biomarker of paraneoplastic neurologic autoimmunity}

Anastasia Zekeridou, Thomas Kryzer, Yong Guo, et al.

Neurology 2019;93;e815-e822 Published Online before print July 17, 2019

DOI 10.1212/WNL.0000000000007971

\section{This information is current as of July 17, 2019}

\author{
Updated Information \& \\ Services \\ Supplementary Material \\ References \\ Citations \\ Permissions \& Licensing \\ Reprints
}

including high resolution figures, can be found at: http://n.neurology.org/content/93/8/e815.full

Supplementary material can be found at: http://n.neurology.org/content/suppl/2020/01/31/WNL.0000000000007 971.DC1

This article cites 27 articles, 5 of which you can access for free at: http://n.neurology.org/content/93/8/e815.full\#ref-list-1

This article has been cited by 3 HighWire-hosted articles: http://n.neurology.org/content/93/8/e815.full\#\#otherarticles

Information about reproducing this article in parts (figures,tables) or in its entirety can be found online at:

http://www.neurology.org/about/about_the_journal\#permissions

Information about ordering reprints can be found online: http://n.neurology.org/subscribers/advertise

Neurology ${ }^{\circledR}$ is the official journal of the American Academy of Neurology. Published continuously since 1951, it is now a weekly with 48 issues per year. Copyright Copyright (C) 2019 The Author(s). Published by Wolters Kluwer Health, Inc. on behalf of the American Academy of Neurology.. All rights reserved. Print ISSN: 0028-3878. Online ISSN: 1526-632X.

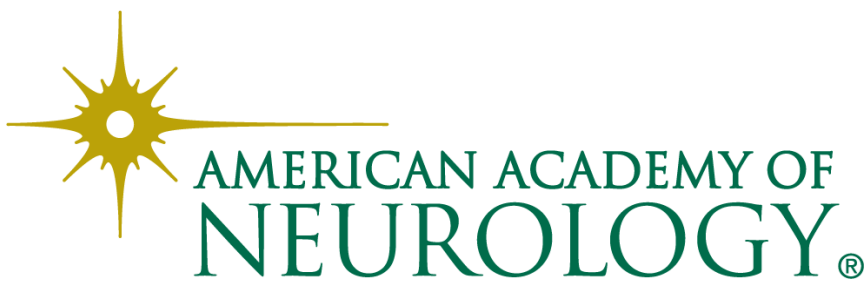

